\title{
A MICROECONOMIC ANALYSIS OF PRODUCTIVITY IN THE MANUFACTURING INDUSTRY OF NORTH WEST
}

\author{
EPJ KLEYNHANS
}

\author{
School of Economics, Risk Management and International Trade, \\ Potchefstroom University for Christian Higher Education
}

\begin{abstract}
This article studies the productivity in the manufacturing industry of the North West Province. Estimates of the Cobb-Douglas production function for the province's manufacturing industry are utilised and then applied to the industry's cost structure to determine whether the factors of production are optimally allocated.

It was found that the levels of labour productivity are continuously declining. Higher gains in output could have
been achieved if expenditure on production factors were optimally allocated. What the optimal allocations should have been are then determined in monetary terms.

Finally the paper accepts that the manufacturing industry is estimating market demand fairly accurately without stockpiling of supplies. The paper then determines what the level of optimisation of the capital and labour input base in the manufacturing industry should have been and what the extent of savings could be if production factors are optimally allocated in the North West Province's manufacturing industry.
\end{abstract}

\section{OPSOMMING}

Die produktiwiteit van die vervaardigingsnywerheid in die Noordwes Provinsie word in hierdie artikel bestudeer.'n Cobb-Douglas produksiefunksie word vir die vervaardingsnywerheid van die provinsie geskat. Die resultate word dan op die nywerheid se kostestrukture toegepas om te bepaal of die produksiefaktore optimaal geallokeer is.

Daar is gevind dat daar 'n kontinue afname in arbeidsproduktiwiteit bestaan. Hoër winste in uitset is moontlik indien besteding aan produksiefaktore optimaal toegewys word. Wat die optimale allokasie moes wees word dan bepaal.

Laastens word aanvaar dat die vervaardigingsnywerheid markvraag redelik akkuraat voorspel sonder ophoping van voorrade. Daar word dan bepaal wat die vlak van optimalisasie van die kapitaal en arbeidsbasis in die vervaardigingsnywerheid behoort te wees en hoeveel die besparings kan wees indien produksiefaktore optimaal geallokeer word in die vervaardigingsnywerheid van Noordwes Provinsie.

The optimal level of the labour and capital input base in the manufacturing industry of the North West Province is investigated in this study. It determines whether the industry was functioning at the optimal level, how much the deviation is costing the industry and how much could be gained when the input combination is rectified.

Van Zyl \& Kleynhans suggested a unique way of determining productivity through the evaluation of the input combination of the factors of production in the issue of the Journal of Industrial Psychology of May 1995. This paper aims to investigate that technique by applying it to the manufacturing industry of the North West Province. The excellence of this method lies in the fact that it expresses productivity or the loss thereof and the possible gains of higher productivity in monetary terms. As the findings are expressed in rand and cent planners can use them directly in their development strategies.

With the elimination of protective tariffs and the globalisation of the South African economy, optimal levels have to be striven for to survive increasing international competition. Future competitiveness is critically dependent on a higher level of cost efficiency and especially on a more productive labour and capital input.

Manufacturing in the province is important as a provider of employment and foreign revenue and it contributes towards the balance of payments and technological advancement. Manufacturing demands locally provided raw and intermediate materials and helps to alleviate of poverty in the region.

\footnotetext{
It is unfortunate that more recent statistics is not always available, but it serve to illustrate the general trends.

Requests for copies should be addressed to: EPJ Kleynhans, School of Economics, Risk Management and international Trade, PU for CHE, Private Bag X6001, Potchefstroom,
} 2520 .
It is therefore important to be able to measure and quantify the extent of the perceived lack of productivity. The Cobb-Douglas efficiency criterion provides a straightforward instrument for this purpose. The findings should help industry, labour unions and other interest groups to comprehend the full implications of the low levels of productivity in the industry.

This article will commence with an overview of the economy of the North West Province and its manufacturing industry in particular. Then the theoretical concept of the efficiency criterion will be explained. Next a production function for manufacturing in the province will be estimated, which will provide the elasticities and other variables to estimate the optimal input ratios and efficiency criteria, based on historical achievements. Thereafter the optimal utilisation of the total cost outlay will be determined and lastly the optimal factor allocation warranted by the market demand will be determined. In each case the optimal input combination of the factors of production will be determined, the losses that occurred with the unproductive input combinations and possible gains in monetary terms. The paper concludes by evaluating the merits of the method applied, and suggestions will be formulated that could enhance manufacturing in the province.

\section{THE ECONOMY OF THE NORTH WEST PROVINCE}

The North West Province embraces 9.7 per cent of South Africas soil and houses 8.6 per cent of the population. The population grows at a rate of 2.9 per cent and the region's GGP grows annually at only 1.2 per cent (1980-1991), which implies that the per capita income is declining (Erasmus, 1998:81-82) ${ }^{1}$.

The province provides 5.7 per cent of South Africas GDP (1996). Manufacturing is contributing 10.35 per cent and it is growing at an annual rate of 4.01 per cent, which is the second best of all the provinces (Erasmus, 1998:81-82). 
The unemployment rate is 36.6 per cent (1994), which is four per cent above the national average (Schneider, 1998:85). In 1991 only 48.9 per cent of the extended labour force was formally employed. The low employment levels contribute to the high level of poverty in North West (DBSA, 1995:79).

The North West Province experienced employment growth of 0.55 per cent annually, between 1980 and 1991. The best employment growth rates were in finance, insurance $\&$ real estate, which grew by 4.42 per cent and manufacturing, where employment was growing at 2.66 per cent. These employment growth rates are still much less than their increase in production. This implies that jobless growth occurred in the North West. The only sectors in North West, which experienced negative employment growth were agriculture, mining \& quarrying (DBSA, 1995:117).

The underdeveloped state of the North West's manufacturing is not only evident in its relatively low contribution of twelve per cent to provincial GGP relative to 32 per cent in Gauteng (1998), but in the fact that the whole manufacturing sector is dominated by only three industrial sectors. Fabricated metals $(51 \%)$, non-metallic minerals $(21 \%)$ and food and beverage products (18\%) are responsible for 90 per cent of the province's manufacturing output.

Manufacturing is spatially concentrated with more than 80 per cent of the firms located in the Klerksdorp-Potchefstroom and Rustenburg-Brits districts, in close proximity to Gauteng and the Platinum SDI.

The three dominating industries in North West are all low technology medium-wage and resource-intensive products. The types of industry which would benefit from SouthAfrica's trade liberalisation and the GEAR strategy, like textiles and electronics, are absent from the province (Kleynhans, Naudé \& Suleman, 1998:46).

Similar trends emerge when looking at the value added and capital/labour ratios. In North West, only 60 per cent of manufacturing firms can be classified as high value added industries. In Gauteng it is 76 per cent. This suggests that technology is not as advanced in North West, and more importantly from an investment point of view, that profits are not as high as in Gauteng or other provinces (IDC, 1998a:75).

North West has a low degree of competitiveness ${ }^{2}$. This does not bode well for attempts to encourage investment - especially FDI. Competitiveness is one of the fundamental determinants of investment and of decision by industrialists regarding location (Kleynhans et al. 1998:47).

North West has the lowest R \& D expenditure per person annually (R55000 in real terms) compared to all other provinces (IDC, 1998a:75). In terms of R \& D to GGP, it ranks five out of nine. However, the province boasts two universities (at Potchefstroom and Mafikeng) with significant R\&D expertise and potential.

North West Province in particular has a low degree of internationalisation, and currently exports only 8.4 per cent of the manufacturing output. The province also does not have the same exposure to international tourism as most other provinces do. The province does, however, have much merit in its favour. The advantages to investors in the North West Province are the accessibility of water, electricity and labour. Water electricity, rent, labour, telephone, transport and airfreight is relatively less-expensive than is the case in the rest of the country. The province has a supply of supplier networks, support services, fresh produce, skilled and unskilled labour, infrastructure, internet \& cell phones, roads and aviation.
The rail network comprises critical linkages in the national and regional networks. These are the North-South line (HarareJohannesburg-Cape Town), the East-West line (Maputo-Rustenburg-Gaborone-Windhoek-Walvis Bay) and the Central corridor (Botswana-Zimbabwe-Zambia).

The airports at Pilansberg and Mafikeng are an important hub in the regional air network, especially as far as tourism is concerned. Mafikeng International Airport has amongst the highest ratings and designing standards in Southern Africa.

The meat processing industry has backward and forward linkage potential in such areas as feed production, animal science and breeding, feedlot development, and animal by-products for the fertiliser industry. The North West Province has a comparative advantage in this sector due to the extensive livestock production across the province, particularly in the Vryburg region, which has some of the most favourable conditions for cattle farming in the world, especially in terms of the absence of disease (Kleynhans et al. 1998:48).

Other significant industries are grain milling, edible oils and soaps (where the province can provide the potential investor ample access to raw materials), chemical products and the basic metal industry. An investigation by the Industrial Development Corporation in 1997 has found that North West has a comparative manufacturing advantage in the basic metal, food processing and chemicals industries; it was rated the top province in each of these industries (See Naudé, 1997:26 \& Service group, 1997:25).

Given positive expected prospects for platinum, agro-industries and tourism in years to come, North West is set to experience a phase of growth and development. The province has already succeeded in turning the negative economic growth rates of the 1980s into high positive growth rates during the 1990s. Economic growth is expected to reach between five and six per cent per annum in future (IDC, 1998b:15).

Current real GGP per capita averages around R4 385 per annum but is still characterised by high inequalities, especially between rural and urban areas (Erasmus, 1998:81-82). Human development in the North West Province shows severe spatial disparities. The infant mortality rate per 1000 of the population is 43.3 , which is nearly the same as the national average of 41.8 per cent (Schneider, 1998:85), but for some disadvantaged sections of the population, the infant mortality rates are up to seven times higher (DBSA, 1995:79). Life expectancy in North West is 64.1 years, which is about one year longer than the national average. The province has only 4.5 hospital beds per 1000 of the population, 0.7 less than the South African average; and the dependency rate in the province is about average at 1.6 (Naudé, 1998a:85).

The province has a Human Development Index (HDI) of only 0.543 (1993) compared to the national average of 0.64 (WEFA, 1996:41-45). This HDI is an improvement since 1980 when it was only 0.482 (Naudé, 1998b:66). The Gini coefficient is about average at 0.6 in the North West Province (Whiteford, 1995:21), but it still indicates inequality in the distribution of income and a huge challenge to economists and the authorities in the province. Among the population in the province 41.3 per cent live below the absolute poverty line and the poverty situation is even more acute in the rural areas (Naudé,1998b:61 \& DBSA, 1995a:79).

The structure and context in which manufacturing operates in the North West Province's economy was sketched above. In the following section the theoretical concept of the efficiency criterion will be explained to demonstrate how this study was done.

\section{THE EFFICIENCY CRITERION}

The theoretically purist and most widely used production function is the Cobb-Douglas function (Van Zyl 1995:6) which 
states the relationship of labour $(\mathrm{L})$ and capital $(\mathrm{K})$ to output (Q) as: $\mathrm{Q}=\mathrm{aK}^{\alpha} \mathrm{L}^{\beta}$. The level of technology is indicated by "a". Parameter $\alpha$ is the output elasticity of capital and $\beta$ the output elasticity of labour. Parameter $\beta$ denotes the percentage change in output as a result of a percentage change in labour input, keeping capital constant (Cobb \& Douglas, 1928:139165).

The Cobb-Douglas production function is estimated by converting the function $\mathrm{Q}=\mathrm{aK}^{\alpha} \mathrm{L}^{\beta}$ to $\mathrm{Q}=\log \mathrm{a}+\alpha \log$ $\mathrm{K}+\beta \log \mathrm{L}$. By means of linear regression analysis parameters a, $\alpha$ and $\beta$ are determined. The marginal products of labour and capital are respectively $\mathrm{MP}_{\mathrm{L}}=\beta(\mathrm{Q} / \mathrm{L})$ and $\mathrm{MP}_{\mathrm{K}}=\alpha(\mathrm{Q} / \mathrm{K})$. The optimal cost efficient utilisation of production factors is obtained at the point where the last $\mathrm{R}$ and is spent all factors yields equal marginal products: $;\left(\mathrm{MP}_{\mathrm{L}} / \mathrm{w}\right)=\left(\mathrm{MP}_{\mathrm{K}} / \mathrm{r}\right)$ where $\mathrm{w}$ is the unit wage cost and $\mathrm{r}$ the unit cost of capital. The estimated production function can now be used to determine whether the input combination of an industry is optimal or sub-optimal (Van Zyl \& Kleynhans, 1995:6).

When $\mathrm{MP}_{\mathrm{L}} / \mathrm{MP}_{\mathrm{K}}<\mathrm{w} / \mathrm{r}$ it is an indication of over-utilisation of labour, indicating a decline in labour productivity. On the other hand, if $\mathrm{MP}_{\mathrm{L}} / \mathrm{MP}_{\mathrm{K}}>\mathrm{w} / \mathrm{r}$, capital is over-utilised, indicating a decline in the productivity of the capital goods used and an overutilisation of labour, ceteris paribus. The marginal rate of technical substitution of labour for capital is: $\mathrm{MRTS}=\mathrm{MP}_{\mathrm{L}} / \mathrm{MP}_{\mathrm{K}}=$ $(\beta / \alpha)$. $(\mathrm{K} / \mathrm{L})$. The optimum input mix of labour and capital is then at the point where $\mathrm{w} / \mathrm{r}=(\beta / \alpha) .(\mathrm{K} / \mathrm{L})$ or $(\beta / \alpha) .(\mathrm{K} / \mathrm{L})$ $-(\mathrm{w} / \mathrm{r})=0$. Multiplying by $\alpha$ yields the input efficiency criterion $\Psi=\beta(\mathrm{K} / \mathrm{L})-\alpha(\mathrm{w} / \mathrm{r})=0$. If $\beta(\mathrm{K} / \mathrm{L})-\alpha(\mathrm{w} / \mathrm{r})<0$ (thus $\Psi<0$ ) the industry is experiencing a decline in labour productivity since $\Psi<0$ implies that $\left(\mathrm{MP}_{\mathrm{L}} / \mathrm{MP}_{\mathrm{K}}\right)<(\mathrm{w} / \mathrm{r})$ (Maurice and Smithson, 1985:126-130).

The prices of the factors of production can be calculated in various ways. The input price of labour $(\mathrm{w})$ is obtained by dividing total salaries and wages by the number of employees. To make the price of wages comparable to the price of capital, the average wages (in R'000) per annum are deflated by the production price index. The input price of capital $(r)$ is generally expressed as $r=Q_{K}(i+\delta)$ where $Q_{K}$ is the unit acquisition cost of the capital stock. The rate of depreciation $(\delta)$ is calculated as the percentage of total capital depreciation and the real interest rates were obtained by deflating the long run Escom rate by the PPI.

Data for the years 1970 to 1995 were obtained from WEFA, StatsSA and the Quarterly Bulletins of the South African Reserve Bank. The production function for the manufacturing industry of North West was then estimated as $Q=10.541$ $\mathrm{K}^{0,548} \mathrm{~L}^{0,499}$, with a $\mathrm{R}^{2}$ of 98 (Fourie, 2000:32)*. The output elasticity of labour $(\beta)$ implies that a ten per cent increase in labour productivity would result in a 4.99 per cent increase in output, ceteris paribus. This indicates that the industry is not very labour intensive. The industry is regarded as labour intensive when more is spend on labour than on capital goods in the production process, when $\beta$ is larger than $\alpha$ and/or the point of production on the isoquant graph is to the right of the point of optimisation - employing more labour.

As in Van Zyl et al. (1994:5-7) the optimal utilisation of the labour component is expressed by the efficiency criteria $(\Psi)$ which is calculated utilising the formula $\Psi=\beta(\mathrm{K} / \mathrm{L})-$ $\alpha(\mathrm{w} / \mathrm{r})$ as indicated in the theoretical exposition above.

The results for the period 1970-1995 are shown in Table 1. It is evident from the table that $\Psi<0$ for most of the 26 production years, irrespective of the business cycle phases and since 1987 labour was over-utilised in every year. This is an indi-

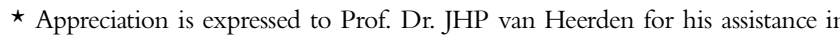
estimating the production function; and assistant PJ Fourie for his preliminary investigation of the theme.
}

cation of a continuous decline in the level of labour productivity. The next step is to quantify the decline in labour productivity in terms of cost wastage (in Rand).

TABLE 1

EFFICIENCY CRITERIUM $(\Psi)$

\begin{tabular}{|c|c|c|}
\hline Year & $\Psi$ & $\begin{array}{c}\text { Input } \\
\text { over-utilisation }\end{array}$ \\
\hline 1970 & -185.243 & $\mathrm{~L}$ \\
\hline 1971 & -45.154 & $\mathrm{~L}$ \\
\hline 1972 & -57.1995 & $\mathrm{~L}$ \\
\hline 1973 & 12.47374 & $\mathrm{~K}$ \\
\hline 1974 & 13.1072 & $\mathrm{~K}$ \\
\hline 1975 & 20.52269 & $\mathrm{~K}$ \\
\hline 1976 & 30.88467 & $\mathrm{~K}$ \\
\hline 1977 & 90.51764 & $\mathrm{~K}$ \\
\hline 1978 & -574.411 & $\mathrm{~L}$ \\
\hline 1979 & 18.11745 & $\mathrm{~K}$ \\
\hline 1980 & 29.26706 & $\mathrm{~K}$ \\
\hline 1981 & 322.1764 & $\mathrm{~K}$ \\
\hline 1982 & 64.90608 & $\mathrm{~K}$ \\
\hline 1983 & -52.2772 & $\mathrm{~L}$ \\
\hline 1984 & -24.7052 & $\mathrm{~L}$ \\
\hline 1985 & -151.745 & $\mathrm{~L}$ \\
\hline 1986 & 68.55199 & $\mathrm{~K}$ \\
\hline 1987 & -197.723 & $\mathrm{~L}$ \\
\hline 1988 & -94.1441 & $\mathrm{~L}$ \\
\hline 1989 & -720.424 & $\mathrm{~L}$ \\
\hline 1990 & -117.068 & $\mathrm{~L}$ \\
\hline 1991 & -102.598 & $\mathrm{~L}$ \\
\hline 1992 & -54.3686 & $\mathrm{~L}$ \\
\hline 1993 & -1300.21 & $\mathrm{~L}$ \\
\hline 1994 & -94.753 & L \\
\hline 1995 & -185.528 & $\mathrm{~L}$ \\
\hline
\end{tabular}

\section{THE OPTIMUM UTILISATION OF THE TOTAL COST OUTLAY}

The optimal input ratio of labour and capital (z) must be such that $\mathrm{K} / \mathrm{L}=(\alpha \mathrm{w}) /(\beta \mathrm{r})$. The optimum allocation of the labour input can be calculated from the optimal input ratio. Thus $\mathrm{L}_{\mathrm{o}}=(\beta \mathrm{rK}) /(\alpha \mathrm{w})$. The optimum allocation of the labour input can also be derived from the isocost line for a specific cost outlay $\mathrm{C}=\mathrm{rK}+\mathrm{wL}$ and $\mathrm{L}=(\mathrm{C}-\mathrm{rK}) / \mathrm{w}$.

Levels of production where $\Psi=0$ are rarely found in practice. Should the calculations show no optimal input allocation, it must be determined whether the calculated $\Psi$ is significantly different from 0 . This is done by means of a t-test. The calculated t-statistic is $t=\Psi / S \Psi . S \Psi$ is the estimated $\Psi$ 's own standard error and the estimated variance of $\Psi$ can be calculated as: $\operatorname{Var}(\Psi)=(\mathrm{K} / \mathrm{L})^{2} \operatorname{Var}(\beta)+(\mathrm{w} / \mathrm{r})^{2} \operatorname{Var}(\alpha)-2(\mathrm{~K} / \mathrm{L})(\mathrm{w} / \mathrm{r})$ $\operatorname{Cov}(\alpha, \beta)$. The estimated standard error of $\Psi$ is:

$\mathrm{S}_{\Psi}=\sqrt{\operatorname{Var}(\Psi)}$. The absolute t-value of $\Psi$ is then calculated. Should it exceed the critical t-value, it can be said that $\Psi$ is significantly different from zero (Maurice \& Smithson, 1985: 128-130).

When evaluating the optimum total cost outlay, it is important to take note of the intensity factor and the factor demand equations, derived from the Cobb-Douglas function. The intensity factor is $(\beta / \alpha)$; the higher this ratio the more labour intensive the production technique (Koutsoyiannis, 1979:65). When $\Psi=0, \beta(\mathrm{K} / \mathrm{L})-\alpha(\mathrm{w} / \mathrm{r})=0$ thus

$$
\mathrm{L}=\mathrm{K}(\beta / \alpha)(\mathrm{r} / \mathrm{w}) \text {. }
$$

Substituting $\mathrm{K}$ and $\mathrm{L}$ in the production function the factor demand equations are derived in terms of output and relative factor prices $\mathrm{L}_{\mathrm{d}}=\left[\mathrm{Q} / \mathrm{L}(\mathrm{r} / \mathrm{w} \cdot \beta / \alpha)^{\alpha}\right]^{1 /(\alpha+\beta)}$ (Heatfield, 1987:82).

The low levels of labour productivity in the industry over the period 1970-1995 had an adverse effect on the output level. From the results (see table 2 ) it is evident that a better utilisation (input mix) of the cost outlay would have resulted in a higher output level. 
The possible optimal output gain was calculated for every year since 1970

For example, 1995: K = R1.484m; $\mathrm{L}=57.345 ; \mathrm{w}=15$ 608; $\mathrm{r}=$ 0,$0461 ; \Psi=-185,578$ indicating an over-utilised labour situation with declining productivity.

The true $\mathrm{K} / \mathrm{L}$ ratio employed was $\mathrm{K} / \mathrm{L}=12.98433$, while the optimal ratio should have been: $(\mathrm{K} / \mathrm{L})_{0}$ ratio $=\mathrm{z}=(\alpha \mathrm{w}) /(\beta \mathrm{r})$ $=371.825-$ indicating that the capital to labour input base was sub-optimal.

The money spent on the factors of production was: $\mathrm{C}=\mathrm{rK}+$ $\mathrm{wL} ; \mathrm{C}=\mathrm{R} 895.13 \mathrm{~m}$

The optimal input levels of capital and labour should have been:

$\mathrm{K}_{0}=(\alpha \mathrm{C}) /(\mathrm{r} \epsilon)=\mathrm{R} 101.82 \mathrm{~m}$ where $\epsilon=(\alpha+\beta)$ and $\mathrm{L}_{0}=(\beta \mathrm{rK}) /(\alpha \mathrm{w})=27385$ workers

Test: $\mathrm{K}_{0} / \mathrm{L}_{0}=371.825$

The level of production was calculated as: $\mathrm{Q}=\mathrm{aK}^{\alpha} \mathrm{L}^{\beta}$

The amount produced in that year was: $Q_{\text {true }}=\mathrm{R} 3100.272 \mathrm{~m}$, but at the point of optimisation $\mathrm{Q}_{\mathrm{o}}=\mathrm{R} 271.33 \mathrm{~m}$ could have been produced utilising the same cost outlay.

The inefficiency output loss was: $Q_{0}-Q_{\text {true }}=R 68.23 \mathrm{~m}$, where "O" indicates optimal and "true" the amount that was really occurred in that year.

The inefficient labour component is calculated as: $\mathrm{L}_{\text {true }}-\mathrm{L}_{\mathrm{o}}=$ 29959 excess workers.

Table 2 shows the possible output wasted in each year (19871995) and the unproductive labour that was employed at the non-optimal factor allocation and total cost outlay levels.

TABLE 2

NON-OPTIMAL UTILISATION OF THE TOTAL COST OUTLAY

\begin{tabular}{ccc}
\hline Year & $\begin{array}{c}\text { Output loss } \\
\text { (R mil.) }\end{array}$ & $\begin{array}{c}\text { Unproductive labour } \\
\text { (excess workers) }\end{array}$ \\
\hline 1987 & 300.3 & 32223 \\
1988 & 210.7 & 34020 \\
1989 & 658.8 & 34526 \\
1990 & 244.9 & 34997 \\
1991 & 222.8 & 34309 \\
1992 & 146.3 & 32219 \\
1993 & 811.9 & 30919 \\
1994 & 187.9 & 30444 \\
1995 & 268.2 & 29960 \\
\hline
\end{tabular}

From the table, it is obvious that the calculated output loss as a result of the employment of unproductive labour remained relatively high over the entire period.

\section{OPTIMAL FACTOR ALLOCATION ACCORDING TO MARKET DEMAND}

Producing a higher output when an alternative optimal input combination is applied at the same cost-outlay would be unwise. Motor vehicles manufactured in South Africa are, for instance, sold within six weeks (Van Zyl \& Kleynhans, 1995:8) to produce more would be a waste. The assumption in this paper is then also made that manufacturers are already supplying what the market currently demands. It is therefore better to continue manufacturing the same amount of output, but at an optimal input combination of production factors.

When an optimal factor allocation at a given labour and capital cost has been determined for a particular cost outlay, it can be used to determine the optimal factor allocation warranted by the market demand.

The optimum amount of labour in the industry required to meet market demand can be calculated by the use of the formula $\mathrm{L}_{\mathrm{D}}=\sqrt[\epsilon]{\left.\mathrm{Q}_{\mathrm{D}} / \mathrm{Z}^{\alpha} \mathrm{L}\right)}$ where $\mathrm{Z}=$ optimal $\mathrm{K} / \mathrm{L}=(\alpha \mathrm{w}) /(\beta \mathrm{r})$. The optimal capital input can be determined by $\mathrm{K}_{\mathrm{D}}=$ $\sqrt[\alpha]{\mathrm{Q}_{\mathrm{D}} /\left(\mathrm{aL}_{\mathrm{D}}^{\beta}\right)}$ (Van Zyl \& Kleynhans, 1995:8-10).

Table 3 lists the non-productive labour component per level of market demand and the possible cost gain as a result of better factor utilisation, for each year during 1978-1995. It can be seen from Table 3 that the manufacturing industry is burdened by a significant number of non-productive labourers. These figures are disturbing when compared with the relevant facts. Real wages increased relatively, while the number of non-productive labourers had increased. This is an indication of a continuous decline in labour productivity.

TABLE 3

FACTOR WASTAGE ACCORDING TO MARKET DEMAND

\begin{tabular}{ccc}
\hline Year & $\begin{array}{c}\text { Unproductive } \\
\text { labour }\end{array}$ & $\begin{array}{c}\text { Possible cost gain } \\
\text { with less labour } \\
\text { employed } \\
\text { (R mil. - real prices) }\end{array}$ \\
\hline 1987 & 61659 & 146.8146 \\
1988 & 65093 & 62.93753 \\
1989 & 66072 & 321.6911 \\
1990 & 66968 & 199.2662 \\
1991 & 65651 & 221.7978 \\
1992 & 61654 & 44.95409 \\
1993 & 59172 & 6417.455 \\
1994 & 58254 & 204.0643 \\
1995 & 57330 & 376.2697 \\
\hline
\end{tabular}

\section{SUMMARY AND CONCLUSIONS}

\section{A) Evaluation of the Method Used}

The Cobb-Douglas efficiency criteria and in particular its extensions, serve as effective and useful instruments to measure and quantify the extent of a decline in labour productivity in a particular industry.

The method is easy and economical to apply. More elaborate methods to obtain more accurate findings, better production functions and adjusting the figures to include changes in technology do not yield better results (see e.g. Kleynhans, 1996:15). The fact that it measures productivity in Rand and Cent makes this method unique.

The method gives development managers a useful instrument when planning, as it gives the exact number of unproductive labour units and indicates the value of capital that should optimally be applied and the loss due to unproductivily in specific monetary terms. It also indicates what returns can be gained in Rand and Cent terms. In this regard it is not only an indication of the problem of unproductivity but also suggests part of the solution.

The method utilises real values and when real interest rates are negative it is impossible to draw roots when applying it and thus makes this method useless for those years. Alternative interest and inflation rate series might then be employed like the $\mathrm{BA}$ rate or CPI, but this will be less accurate. As companies gain tax gains on their levels of depreciation, it is very difficult to determine the true value of depreciation. Companies are also reluctant to release their production figures to others for research purposes. Indexes are, however, more readily available and the same technique could be employed to determine the percentages of unproductive labour and the percentages with which inputs should change and how that will alter production figures and costs. Within firms this method can, however, be used with ease as well as by investment institutions where firms have to declare their figures to obtain funds.

\section{B) Productivity in the North West Province}

The results of the efficiency criteria measurements do indeed substantiate the view that the continuous decline in labour productivity in the manufacturing industry of North West is one of the more important causes of rising market prices. The key challenge facing all those associated with the industry is the improvement of labour productivity at a time when the overall productivity trend remains under pressure and wages and other costs have been rising at a faster rate than those of the overseas competitors have. The alternative is to employ more capital goods, mechanise, implement robotics and retrench those unproductive labourers. 
The demands of the labour unions have probably compelled the industry to employ more labour at higher wage levels than would have been the case had management been at liberty to act more rationally. The low level of productivity per worker can probably also be attributed to the low worker ethics generally prevalent in the South African work force. The findings of this paper agree with those of Van Zyl \& Kleynhans (1995:8) and studies like the Riley Report (IDC, 1993:99-102) of the Motor Industry Task Group that South African industries are too labour intensive. Since 1995 major changes and restructuring have also occurred resulting in job losses, which has worsened the situation. It did however raised competitiveness, which might create more employment in the longer term. Should the decline in labour productivity remain unchallenged, thousands of workers will have to be retrenched in order to bring unit cost down and make the industry more competitive.

\section{REFERENCES}

Agrell, P.J. \& Martin, W.B. (2001). A caveat on the measurement of productive efficiency. International Journal of Production Economics. 69(1), 1-14.

Bloch, H. \& Sam Hak Kan, T. (1999). Technical change and total factor productivity growth. Applied Economic Letters. 6(10), 697-703.

Cobb, CW \& Douglas, P.H. (1928). Theory of production, American Economic Review. 23rd supplement, 139-65.

Corrado, C. \& Lawrence, S. (1999). Decomposition of productivity and unit costs. American Economic Review. 89(2), 32833.

De Wet, T.J. (1998). A supply side approach for estimating a production function for The South African economy. Paper presented at the Third Annual Conference for Econometric Modelling in Africa. Pretoria: University of Pretoria.

DBSA. (Development Bank of Southern Africa). (1995). South Africa's nine provinces: A human development profile. Development information paper 28. 2nd ed. Halfway House. Development Bank of Southern Africa. Compiled by J. Erasmus. Mar. 1995.

Du Plooy, R.M. (1988). Productivity in South African industry. South African Journal of Economics. 56(1), 82-93.

Erasmus, J. (1998): Development profile of North West Province. Development paper 116. Halfway House. Development Bank of South Africa.

Fourie, P.J. (2000). Die toewysing van produksiefaktore in die Noordwes Provinsie se vervaardigingsektor. Hons.B.Com. project. Potchefstroom: PU for CHE

Harrigan, J. (1999). Estimation of cross-country differences in industry production functions. Journal of International Economics, 47(2), 267-91.

Heathfield, D.F. (1987). Introduction to cost and production functions. London: McMillan.

Heintz, J. (2000). Productivity benefits for all. Productivity. 26(1), 13-15.

IDC see Industrial Development Corporation.

Industrial Development Corporation of South Africa. (1993). Study of the competitiveness of the South African Motor Vehicle Industry. Sandton: IDC.

Industrial Development Corporation (1998a). The Platinum Spatial Development Initiative: Scope for industrial development. Report compiled by Platinum Consortium and Potchefstroom University. Sandton: IDC.

Industrial Development Corporation (1998b). Provincial sectoral prospects. Sectoral paper series (SS5/1998). Compiled by Coetzee, R \& Joubert, R. Sandton. Industrial development corporation of South Africa limited. Oct. 1998.

ITRISA. 2001. International Monetary Relations. Johannesburg: International Trade Institute of South Africa.

Jovanovic, B. \& Dmitriy, S. (2000). Optimal adoption of complimentary technologies. American Economic Review. 90(1), 15-30.
Kleynhans, E.P.J. (1994). The level of optimalization of the capital and labour input base in the South African motor vehicle industry. M.A.- dissertation. Auckland Park, Rand Afrikaans University.

Kleynhans, E.P.J. (1996). Cobb-Douglas versus CES and Transcendental logarithmic production functions. Paper delivered at the EBM Research conference at the University of Port Elizabeth.

Kleynhans, E.P.J. (2001). The contribution of spatial development initiatives to regional manufacturing development in South Africa. Unpublished Ph.D. thesis, Potchefstroom University for Christian Higher Education: Potchefstroom.

Kleynhans, E.P.J.; Naudé, W.A. \& Suleman, A. (1998). Regional industrialisation in South Africa with special reference to the Platinum Spatial Development Initiative. Paper delivered at the Annual Forum of the Trade and Industrial Policy Secretariat. Muldersdrift.

Koutsoyiannis, A. (1979). Modern microeconomics. 2nd ed. London: McMillan.

Levy, D. (1994). Output, capital, and labor in the short and long run. Southern Economic Journal, 60(4), 946-61.

Maurice, S.C. \& Smithson, S.W. (1985). Managerial economics, Applied microeconomics for decision-making. Homewood: Irwin.

Moreton, D. (1999). A model of labour productivity and union density in British private sector. Oxford Economic Papers, 51(2), 322-45.

Naudé, W.A. (1997). Economic development concepts and issues in South Africa. Potchefstroom: Potchefstroom University. TLS.

Naudé, W.A. (1998). On the Platinum road. The South Africa Report, 1, 1998, 82-7.

Piazolo, M. \& Wurth, M. (1995). Productivity in the South African manufacturing industry: a cointegration technique. South African Journal of Economics, 63(2), 173-96.

Pine, B. (1992). Total factor productivity vs. realism. South African Journal of Economics, 60(3), 277-92.

Ramirez, M.D. (1998). Does Public Investment Enhance Labor Productivity Growth in Chile? A Cointegration Analysis. North American Journal of Economics \& Finance, 9(1), $1-45$.

Renuka, M. \& Kalirajan, K.P. (1999). On measuring total factor productivity growth in Singapore's manufacturing industries. Applied Economic Letters, 6(5), 295-9.

Service group, Inc. (1997). North West Province investor targeting strategy. Draft report. Prepared for Investment South Africa, May 1996.

Schneider, M. ed. (1998). The South African Report. South Africa's Reconstruction and Development Magazine. 1998 (1).

Stiroh, K.J. (2001). What drives productivity growths? Economic Policy Review. 7(1), 37-60.

Van Zyl, G. \& Kleynhans, E.P.J. (1994). The level of optimalisation of capital and labour in the motor vehicle industry. Unpublished research paper for the motor vehicle research unit at the Rand Afrikaans University.

Van Zyl, G. \& Kleynhans, E.P.J. (1995). A Cobb- Douglas estimation of labour productivity in the South African motor vehicle manufacturing industry. Journal of Industrial Psychology. 21(1), 6-9.

Valodia, I. (1999). Trade policy, productivity and learning: evidence in South Africa. Development Southern Africa, 16(3), $531-46$.

WEFA (Wharton Econometric Forecasting Associates) (1996). South African Competitiveness Monitor, 4: Provincial Comparisons. Pretoria: WEFA GROUP.

Whiteford, A. et al. (1995). A profile of poverty, inequality and human development. Pretoria: Human Science Research Council.

Zegeye, A. \& Rosenblum, L. (2000). Measuring productivity in an imperfect world. Applied Economics, 32(1), 91-106. 